\title{
IMPACT OF PREPOTENCY IN COCONUT PRODUCTIVITY
}

\author{
K. U. K. NAMPOOTHIRI ${ }^{1}$
}

\begin{abstract}
Identification of prepotent palms among the commonly grown tall cultivars helps in improving the yield substantially. The efforts made in selection of prepotent mother palms and identification at seedling stage is briefly reviewed. The merits and demerits of progeny testing are discussed and future lines of work are indicated.

\section{Introduction}

The concept of prepotency in yield improvement assumes special significance in crops like coconut with a long juvenile period. Harland (1957) defined prepotent palms as mother palms "which inspite of having indiscriminately pollinated by miscellaneous males are sufficiently possessed of dominant yield factors to ensure that their offspring's are also high yielding". He drew an analogy between this concept and the practice in animal breeding where the value of bull is assessed by the milk yield of a group of his daughters. West Coast Tall and East Coast Tall are the traditionally and commonly grown coconut cultivars in India. There were many efforts on identification of desirable mother palms in these cultivars as well as in certain talls grown in other Asian countries. The pros and cons of these methods are reviewed in this paper.
\end{abstract}

\section{Mother palm selection}

Selection, which aims at retention of desired genotypes and elimination of undesirable ones, is a major and important process in crop improvement. Although the required basic information on the gene action involved in the inheritance of concerned characters was not available, selection of mother palm based on yield factors is an age old practice in ail traditional coconut growing countries. But this was done mostly as an art rather than as a science. Coconut breeders could not take advantage of biometrical techniques, presumably clue to the inherent difficulties in perennial crop breeding and lack of required information on quantitative traits in the crop.

The production for mother palm selection involved identification of potential high yielders using some of the easily observable traits which are considered to be associated with yield potential. Most important among these characters are strait stout trunks with even growth, spherical or semispherical crown, short and stout bunch stalks, number of leaves and inflorescences produced, high and consistent yield of nuts, high copra outturn and freedom from diseases and pests (Menon and Pandalai, 1958; Sampson, 1923). Out of these, maximum attention is usually paid to the yield of nuts. In India 80 nuts per palm per year is taken as the standard where as in Sri Lanka the standard fixed is 100 nuts with an average husked nut weight of $680 \mathrm{gm}$ and in Malaysia palms which yield not less than 100 nuts annually with a weight of $500 \mathrm{gm} / \mathrm{nut}$ are considered suitable for seed nut collection.

In Sri Lanka, Liyanage (1964) found that a higher frequency of palms with high breeding value could be obtained if the best $10 \%$ palms of a population are selected on the basis of copra yield. Since high heritability values of 0.67 and 0.95 have been reported for yield of copra and weight per husked nut respectively and there is significant correlation between these characters,

\footnotetext{
${ }^{1}$ Scientist in charge, Central Plantation Crops Research Institute (Research Centre), Palode 695 562, Thiruvananthapuram, Kerala State, India.
} 
weight of husked nut is taken as a reliable character for selection (Liyanage and Sakai, 1961). It is also suggested that the palms which show less loss in weight of embryo on self pollination should be selected because these are likely to have better breeding value. Although this is a quicker method requiring only 12 months for evaluation, it is not known to have been used except in a few selection prograrnmes in Sri Lanka. Bourdeix (1988) reviewing the effectiveness of mass selection methods in West African Talls concluded that "methods based on the exploitation of between ecotype heterosis guarantee faster genetic progresses".

\section{Yield attributes}

Usefulness of giving attention to yield attributes in addition to the actual end product was later recognised. Liyanage (1967) found that there was significant correlation between number of leaves produced during the first 40 months and yield of copra in 13-14 years. Nambiar and Nambiar (1970) indicated that heritability estimates were higher for number of female flowers and percentage set. Based on studies on underplanted palms Satyabalan et al (1972) suggested that the yield potential can be measured from the initial yield, height and number of functioning leaves since these are significantly correlated with yield. Nambiar and Ravindran (1974) brought out data to show that selection of genotypes with low variance for female flower distribution and more number of spikes with one female tend to ensure steady and increased productivity.

Path coefficient analysis for yield of nuts showed that number of female flowers, number of functioning leaves at 19 years and internodal distance directly or indirectly influenced the yield and are therefore of selection value (Sukumaran et al, 1981). In the same year Louis (1981) recommended number of leaves produced per year, number of leaves on the crown, number of spathes per year, number of female flowers and setting percentage as yield attributes which can be relied upon for selection. But the view of Nampoothiri et al (1975) that phenotypic correlations can be misleading and characters which show high genetic correlations should be given importance has to be given serious consideration. They found girth at collar and leaf production in the nursery were genetically correlated with yield of adult palms.

\section{Isolated seed gardens}

Ziller (1962) suggested establishment of isolated seed gardens. In this a plot isolated from all outside sources of pollen is necessary. The palms with unfavourable characteristics are to be either removed or emasculated so that the quality of pollen in the atmosphere is improved. Though its basis is well accepted, it is not known to have been used systematically anywhere for improvement of tall cultivars.

\section{Elite palms}

Iyer et al (1979) surveyed natural population of West Coast Tall during a period of five years and found that there were palms which yield from 200 nuts to an incredible level of 600 nuts per year as against the national average of 35 nuts. Nineteen such palms were identified and were called 'elite palms'. Many of these were also tolerant to root (Wilt) disease.

The elite palms had a spherical or hemispherical canopy as against the drooping or angular crown generally seen in low yielder (Bavappa and Nampoothiri, 1974). Large number of leaves and non buckling bunches were also characteristic of these palms. A large number of vegetative and floral characters were recorded for developing an ideotype for coconut (Iyer et al, 1981). Here again apart from the use of a few palms for evaluating their inter se and self pollinated progenies for disease tolerance no further utilization has been made. 


\section{The concept of prepotency}

Harland (1957) proposed this concept based on his experience in maize and in analogy with animal breeding methods. He argued that if a paired cross is superior it means that in some way the genetical factors combine to give good results. So also when single mother's arc crossed with many pollen parents the progeny yield will fall on a normal curve with the very rare high transmitters occupying the upper end of the curve. In other words given a sufficiently high number of progenies from open pollinated mothers it should be possible to arrange them in order of yield and pick out mothers which inspite of having been indiscriminately pollinated by miscellaneous males arc sufficiently possessed of dominant yield factors to ensure that their offspring's arc also high yielding. There palms arc designated as prepotent palms. Though the genetic basis of prepotency is not worked out properly it is taken as the general combining ability (Satyabalan and Mathew, 1983). It is possible that it results from the cumulative action of favourable dominant genes.

It is common knowledge that the phenotypic yield expression is due to genetic and environmental factors. Therefore selection of a palm based on its phenotypic characters often do not yield the desired results since the environmental effects arc rarely totally eliminated. It is therefore necessary to study the performance of open pollinated progenies based on which prepotents should be selected.

\section{Early identification}

Since study of adult palm progenies is time consuming and laborious, attention was diverted to the possibility of identifying prepotents through seedlings. There arc many publications on the correlation of seedling characters with adult palms. A few of them which directly relate to prepotency studies arc reviewed here.

Ninan and Pankajakshan (1961) studied the relationship between yield and seedling characters of progenies and found that some high yielders showed markedly superior progeny performance than others. Ninan et al (1964) indicated the possibility of identifying prepotent palms on the basis of growth of one year old nursery seedlings. Satyabalan and Jacob Mathew (1983) studied the collar girth and leaf production in the nursery and indicated the possibility of identifying prepotents based on these characters in the fifth month itself as against the general practice of selection among one year old seedlings. These characters have been earlier found to be genetically correlated with the yield of adult palms.

When lyer et al (1981) compared seedling progenies from 19 elite palms with progenies of prepotent palms, it was found that progenies of two elite palms were even superior to prepotent palms (identified earlier) for seedling characters.

\section{The limitations and future scope}

One major constraint in the identification and study of prepotents is that the percentage of high yielders in a population is very low. Added to that all such high yielders need not necessarily yield high yielding progenies. Utilization of such palms will be possible only through tissue culture which is a far cry as of now.

In a plantation of 1400 palms in Kasaragod (India) high yielders formed only 8.6 percent of the trees while poor yielders constituted $32 \%$ of the population. Venkateswaran et al (1975) reported from a study of East Coast tall coconut plantation in Tamil Naclu, India that 5.9 percent high yielders in a population gave $18.5 \%$ of the total yield. Studies of Satyabalan (1982) revealed that the percentage of palms yielding above 80 nuts in a coconut grove is very low compared to those in the yield range of 40 to 80 nuts. The preportion of prepotent palms is still much lower. 
Through progeny trial Liyanage and Sakai, (1961) could identify only one out of nine selected high yielders in Sri Lanka as transmitting the high copra yield to progenies. He was later able to identify only one palm as prepotent in a progeny trial involving 104 palms based on phenotypic and breeding values. He therefore came to the conclusion that only one percent palms in a population is likely to be prepotent (Liyanage, t967).

Satyabalan et al (1975) studied the performance including the yield of progenies of eight West Coast tall palms and found three of them were prepotents. This indicates that the proportion of such palms depends on the extent of selection pressure applied on the original population. Nampoothiri (1-977) found that six palms out of 40 West African Talls studied could be regarded as good mother palms. Performance of 20 progenies each of 15 palms from Kuttiadi area of Kerala State (India) showed that two of them were prepotents since only these transmitted their high yielding potential to the progenies (KAU, 1977). Investigations conducted by Jack (1929) in Malaysia, Murray (1950) in Trinidad, Cramer in Fiji and Liyanage in Sri Lanka ail indicate the same trend. Table 1. Which details the results of such studies substantiates the point further (Satyabalan, 1982).

\section{Impact of the prepotency concept}

Ever since Harland proposed the theory of prepotency in 1957 there has been no difference of opinion on the usefulness of the technique in improving the yield levels of coconut substantially. But unfortunately studies on this aspect were only handful resulting in very little impact in the overall yield improvement. This could be because of the time lag of experimentation, large resources required, necessity of keeping accurate palm-wise data continuously for many years etc. The overwhelming success of coconut hybrids during middle of the century also tempted the breeders to devote more attention to production and evaluation of various hybrid combinations and neglect selection programmes. Coupled to that it became apparently clear that the percentage of prepotents which could be identified after such long painstaking studies is exceedingly low.

Inspite of all these the coconut breeders should realize the significance of such studies because of the quantum of selection advance one could achieve. Moreover once a prepotent palm is identified large number of its progenies with predictable yield can be produced for further use in selection and hybridisation. Unfortunately studies on the efficacy of prepotents as pollen parents is not known to have been taken up.

Having recognized the importance of the concept, the procedure adopted in identification of prepotents has to incorporate all the information available on selection methodology in the crop. It should involve selection of very high yielders (150 nuts/palm/year and above) coupled with yield attributes and special features like disease resistance (wherever relevant), nursery evaluation, stringent seedling selection, systematic progeny testing and simultaneous evaluation of its utility as pollen parent and the final selection. Such detailed investigations resulting in identification of the best few prepotent palms followed by their full utilization in the coconut breeding programmes will be rewarding. 
Table 1. Distributions of palms according to yield in some coconut growing countries.

\begin{tabular}{|c|c|c|c|c|c|}
\hline Countries & $\begin{array}{l}\text { No. of palms } \\
\text { studied }\end{array}$ & Yield group & $\begin{array}{l}\text { Percentage of } \\
\text { palms in the } \\
\text { group }\end{array}$ & $\begin{array}{l}\text { Percentage } \\
\text { contribution }\end{array}$ & Reference \\
\hline \multicolumn{6}{|l|}{ SRI LANKA } \\
\hline Bandirippuwa & 296 & Low & 45.0 & 30.0 & Menon, K.P.V. \& \\
\hline Estate & & High & 55.0 & 70.0 & Pandalai, K.M. (1958) \\
\hline \multirow[t]{3}{*}{ MALAYSIA } & 388 & 35 & 23.2 & 11.1 & Jack, H.W. (1929) \\
\hline & & $35-85$ & 57.7 & 59.4 & \\
\hline & & 85 & 19.1 & 29.5 & \\
\hline \multicolumn{6}{|l|}{ PHILIPPINES } \\
\hline \multirow[t]{3}{*}{ Laguna } & 4703 & 40 & 90.7 & N.A. & Rodrigo, P.A. et al (1962) \\
\hline & & $40-80$ & 9.3 & & \\
\hline & & 80 & 0.0 & & \\
\hline \multirow[t]{3}{*}{ Quezon } & 5149 & 40 & 40.9 & N.A. & Rodrigo, P.A. et al (1962) \\
\hline & & $40-80$ & 55.0 & & \\
\hline & & 80 & 4.1 & & \\
\hline \multirow[t]{3}{*}{ Quezon } & & 40 & 17.8 & N.A. & Rodrigo, P.A. et al (1962) \\
\hline & & $40-80$ & 51.9 & & \\
\hline & & 80 & 30.3 & & \\
\hline \multicolumn{6}{|l|}{ INDONESIA } \\
\hline \multirow[t]{3}{*}{ Java } & 244 & 40 & 31.9 & N.A. & Cramer, P.J.S. (1951) \\
\hline & & $40-80$ & 48.5 & & \\
\hline & & 80 & 19.6 & & \\
\hline \multicolumn{6}{|l|}{ WEST INDIES } \\
\hline \multirow[t]{3}{*}{ Trinidad } & 600 & Low & 19.0 & 3.0 & Murray. D.E. (1950) \\
\hline & & Medium & 72.0 & 76.0 & \\
\hline & & High & 9.0 & 21.0 & \\
\hline \multicolumn{6}{|l|}{ E. AFRICA } \\
\hline \multirow[t]{2}{*}{ Chambezi } & 278 & 80 & 89.6 & N.A. & Kasembe, J. N. R. \& \\
\hline & & 80 & 10.4 & & Currah, I.A. (1968) \\
\hline \multicolumn{6}{|l|}{ INDIA } \\
\hline Kasaragod & 1400 & 40 & 32.0 & 17.3 & Menon, K.P.V. \& \\
\hline Kerala & & $40-80$ & 59.4 & 66.9 & Pandalai, K.M (1958) \\
\hline Kasaragod & 4347 & 80 & 8.6 & 15.8 & Jacob Mathew et al, \\
\hline \multirow[t]{3}{*}{ Kerala } & & 40 & 31.3 & 17.2 & (1978) \\
\hline & & $40-80$ & 60.3 & 67.6 & \\
\hline & & 80 & 8.4 & 15.3 & \\
\hline Pilicode & 150 & 40 & 29.3 & & Kannan, K. (1982) \\
\hline \multirow[t]{2}{*}{ Kerala } & & $40-80$ & 54.0 & & \\
\hline & & 80 & 16.7 & & \\
\hline Veppankulam & 1668 & 40 & 66.9 & 34.1 & Venkateswaran, A.N. et al \\
\hline \multirow[t]{2}{*}{ Tamil Nadu } & & $40-80$ & 27.2 & 47.4 & $(1975)$ \\
\hline & & 80 & 5.9 & 18.5 & \\
\hline
\end{tabular}

From Satyabalan (1982) 


\section{REFERENCES}

BAVAPPA, K.V.A. \& Nampoothiri, K.U.K. (1974) Recent trends in coconut breeding; Indian J. Genet. 34A : 58-65

BOURDEIX, B. 1988. Effectiveness of mass selection based on yield components in coconut; Oleagineux 43 (7): 291-295.

HARLAND, S.C. 1957. The improvement of coconut palm by breeding and selection. Circulation paper No. 7/57. Bull. 15. Coconut Res. Inst. Ceylon.

IYER, R.D., Rao, E.V.V.B. and Govindan Kutty, M.P. 1979. Super yielders in coconut. Ind. Fmg. 28 (10): 3-5.

IYER. R.D., Rao, E.V.V.B., Sukumaran, C.K. and Jacob, P.M. 1981. Towards an ideal plant type concept in coconut. Proc. PLACROSYM IV, 29-37.

JACK, H.W. 1929. Variation in coconut. Malay. Agric. 17 : 37-38.

K.A.U. 1977. Prepotency studies in West Coast Tall. Reports and papers. Coconut convention. KAU, Kerala. 12-13.

LIYANAGE, D.V. 1961. Genetic improvement of the coconut palm. Proc. 10th Pacif. Science Congress. S. Pacific Comm. Noumea, New Caledonia. 39-50.

LIYANAGE. D.V. 1964. Mass selection and progeny testing in coconuts, work paper No. 4, FAO. Tech. Work Party.

LIYANAGE, D.V. 1967. Identification of genotype of coconut suitable for breeding; Expl. Agric. 3(3): 205-210.

LIYANAGE. D.V. \& Sakai, K.I. 1961. Heritabilities of certain yield characters of the coconut palm. Journal of Genetics 57: 245-252.

LOUIS, I.H. 1981. Genetic variability in coconut palm. Madras Agric. J. 68 : 588-593.

MENEN, K.P.V. and Pandalai, K.M. 1958. The coconut palm -a monograph Indian Central Coconut Committee, Ernakulam.

MURRAY, D.E. 1950. Coconut growing in Trinidad and Tobago. Proc. Agri. Soc. Trin. \& Tobago 50: $193-200$.

NAMBIAR, M.C. and Nambiar, K.P.P. 1970. Genetic Analysis of yield attributes in Cocos nucifera L. Var. West Coast Tall. Euphytica 19: 543-551.

NAMBIAR, M.C. and Ravindran, P.S. 1974. Pattern of Genetic variation in the reproductive characters of coconut. Indian J. Genet. 34 A : 75-82.

NAMPOOTHIRI, K.U.K., Satyabalan, K. and Jacob Mathew 1975.Phenotypic and genotypic correlations of certain characters with yield in coconut. FAO Technical working party on coconut production, production and processing. Kingstom, Jamaica. 
NAMPOOTHIRI, K.U.K. 1977. Variation in production and nutcharacteristics of Nigerian tall coconut with special reference to the selection potential. Technical consultation on oil crops for West and Central Africa. FAO.A.G.P.; OC/77/23.

NIMAN. C.A. and Pankajakshan, A.S. 1961. Progeny studies in coconut 1. Relationship betweem parent yield and seedling characters of progeny with special reference to open pollinated and hybrid progenies of West Coast Talls and its bearing on the concept of prepotency in coconut. Indian Cocon. J. 16: 100-109.

NINAN, C.A. Pankajakshan, A.S. and Abdu, K.M. 1964. Some observations on growth rate and vigour of coconut seedlings. Indian Coconut J. 18: 12-17.

SAMPSON, H.C. 1923. The coconut palm. John Bale, Sons \& Danielson Ltd. London.

SATYABALAN, K. 1982. Yield capacity and transmitting power of mother palms in coconut. Indian Cocon. J. 13: 5-13.

SATYABALAN, K. and Jacob Mathew. 1983. Identification of prepotent palms in WCT coconuts based on the early stages of growth of the progeny in the nursery. Coconut Research and Development. 15-22.

SATYABALAN, K., Jacob Mathew and Radhakrishnann 1972. Yield variation and its relationship with age and growth of under planted coconut palms. Oleagineux 27 (5): 257-259.

SATYABALAN, K., Nampoothiri, K.U.K. and Jacob Mathew. 1975. Identification of prepotent West Coast Tall palms based on progeny performance. Paper presented at the IV session FAO technical working party on coconut production: Protection and Processing. Kingston, Jamaica.

SUKUMARAN, C.K., Narasimhayya, G. and Vijayakumar, G. 1981. Path coefficient analysis in coconut. Proc. PLACROSYM, IV., 191-199.

VENKATESWARAN, A.N., Rajagopalan, R., Ramachandran, M. and Sridharan, C.S. 1975. A study on coconut plantations in Tamil Nadu Coconut Bull. 5: 3-4.

ZILLER, R. 1962. La Selection du cocotier dans le monde. Oleagineux. 17(11): 837-846. 
DR. K.U.K. NAMPOOTHIRI

Dr. K.U.K. Nampoothiri is a Scientist-in-Charge at the Central Plantation Crops Research Institute who specializes in genetic and plant breeding of plantation crops, including coconut, oil palm, arecanut and cocoa. His major research contributions on coconuts included: a tentative classification of Cocos Nucifera based on biosystematic studies; phenotypic and genotypic correlations in relation to yield; identification of prepotent palms in West Coast Tall; initiation of coconut research in Nigeria and prospection and evaluation of hybrids and establishment of a seed garden. The research contributions relating to palm oil, on the other hand, included: indication of possibility of identifying high yielders during early years; identification of pisiferas and initiation of hybrid seed production of commercial tenera. Under this project, three high yielding combinations were evolved, germplasm bank was established, uses of raw palm oil for edible uses was indicated and a small scale palm oil extraction unit was established. Dr. Nampoothiri has 27 years experience in plantation crop research in India and Nigeria and has published 66 papers of scientific and popular in nature. 